\title{
An education program for infection link staff in three Danish hospitals
}

\author{
A Juhl-Jorgensen*, A-M Thye \\ From International Conference on Prevention \& Infection Control (ICPIC 2011) \\ Geneva, Switzerland. 29 June - 2 July 2011
}

\section{Introduction / objectives}

Prevention and control of Healthcare Associated Infections is a priority in the "Danish Quality Model for Public Health", and is part of the accreditation requirements from the Joint Commission International.In order to reduce the number of hospital acquired infections we trained 100 persons from all departments of the three local hospitals as Infection Link Staff.

\section{Methods}

- Use of an education program that is elementary and targeted to the every day running of each department

- Training of at least one person from all the clinical departments

- Holding a training seminar in infection prevention for all Infection Link Staff on three non-consecutive days with an observation study phase between day 2 and 3

\section{Results}

Infection prevention has been brought emphatically into focus. Department leadership and staff are satisfied and hygienic behavior is improving. It still is too early to observe the hoped for reduction of hospital acquired infections.

\section{Conclusion}

The education program needs to be basic and target the every day running of each department and the training of at least one person in all the clinical departments is important so that infection prevention measures can be assured on a daily basis. It is imperative that Infection Link Staff have the full support of Departmental leadership and it requires a sustained effort from the Hygiene Unit to maintain the standard of the Infection Link

Clinical Microbiologi, Hillerod Hospital, Hillerod, Denmark
Staff, as this can easily become victim to sick leaves, overwork, etc.

Continuous education of the Infection Link Staff in the form of networking, receipt of information, participation in seminars, etc. is a must and spread of the concept of Infection Link Staff education to other hospitals is desirable as it appears to be a good way of implementing infection control.

\section{Disclosure of interest}

None declared.

Published: 29 June 2011

doi:10.1186/1753-6561-5-S6-P282

Cite this article as: Juhl-Jorgensen and Thye: An education program for infection link staff in three Danish hospitals. BMC Proceedings 20115 (Suppl 6):P282.
Submit your next manuscript to BioMed Central and take full advantage of:

- Convenient online submission

- Thorough peer review

- No space constraints or color figure charges

- Immediate publication on acceptance

- Inclusion in PubMed, CAS, Scopus and Google Scholar

- Research which is freely available for redistribution
() Bïomed Central

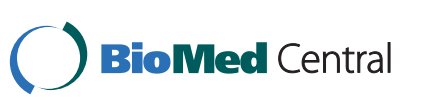

(c) 2011 Juhl-Jorgensen and Thye; licensee BioMed Central Ltd. This is an open access article distributed under the terms of the Creative Commons Attribution License (http://creativecommons.org/licenses/by/2.0), which permits unrestricted use, distribution, and reproduction in any medium, provided the original work is properly cited. 